\title{
Human-Bat Interactions in Rural West Africa
}

\section{Priscilla Anti, Michael Owusu, Olivia Agbenyega, Augustina Annan, Ebenezer Kofi Badu, Evans Ewald Nkrumah, Marco Tschapka, Samuel Oppong, Yaw Adu-Sarkodie, Christian Drosten}

Because some bats host viruses with zoonotic potential, we investigated human-bat interactions in rural Ghana during 2011-2012. Nearly half $(46.6 \%)$ of respondents regularly visited bat caves; $37.4 \%$ had been bitten, scratched, or exposed to bat urine; and $45.6 \%$ ate bat meat. Human-bat interactions in rural Ghana are frequent and diverse.

$\mathrm{B}_{\mathrm{r}}^{\mathrm{a}}$ ats are increasingly being recognized as hosts for pathogens that affect humans and livestock (1). The 2014-2015 outbreak of Ebola virus disease in West Africa demonstrates how human-bat interactions in even remote locations can trigger infection chains that affect global public health and strain the national health care systems in Africa (2). One of the major challenges to preventing batrelated diseases is lack of knowledge about the frequency of, circumstances surrounding, and motivations for human-bat interactions in rural African communities. Only a few quantitative records are available in the scientific literature, and most are not specific for Africa (3).

In Ghana, bats carry potentially zoonotic viruses including lyssa-, corona-, henipa-, and filoviruses (4-6). Although anecdotal knowledge exists with regard to human contact with bats and bat roosts within rural communities and information about the ubiquitous bush meat trade (7), little information is available about the intensity and circumstances of exposure (8). We therefore studied the cultural practices, sociodemographic factors, and religious activities that determine human-bat contact in remote rural communities from which new disease outbreaks have repeatedly emerged (9). Specifically, we studied the sociocultural association of humans with bats in rural communities in Ghana, focusing on potential routes of virus transmission.

\section{The Study}

The study was conducted in 3 communities in Ghana: Kwamang (population 8,000), Forikrom (population 3,800),

Author affiliations: Kwame Nkrumah University of Science and Technology, Kumasi, Ghana (P. Anti, M. Owusu, O. Agbenyega, A. Annan, E.K. Badu, E.E. Nkrumah, S. Oppong, Y. Adu-Sarkodie); University of UIm, UIm, Germany (M. Tschapka); University of Bonn Medical Centre, Bonn, Germany (C. Drosten); German Centre for Infection Research, Bonn (C. Drosten)

DOI: http://dx.doi.org/10.3201/eid2108.142015 and Buoyem (population 3,900). Kwamang is part of the Ashanti Province; Buoyem and Forikrom are in Brong Ahafo Province (Figure 1). Ethics approval was obtained from the Committee for Human Research, Publications and Ethics of Komfo Anokye Teaching Hospital and School of Medical Sciences, Kwame Nkrumah University of Science and Technology, Kumasi.

In each of the 3 communities, in-depth interviews of local leaders were conducted. Buoyem leaders described an activity called the Yam Festival, a hunting festival during which men took ladders to caves on Wednesday evenings and caught bats as they returned from feeding. These bats were described as fruit bats and thus were possibly Rousettus aegyptiacus bats, the species most commonly identified in Buoyem caves. The night's catch was collected by the women; menstruating women were excluded from participation

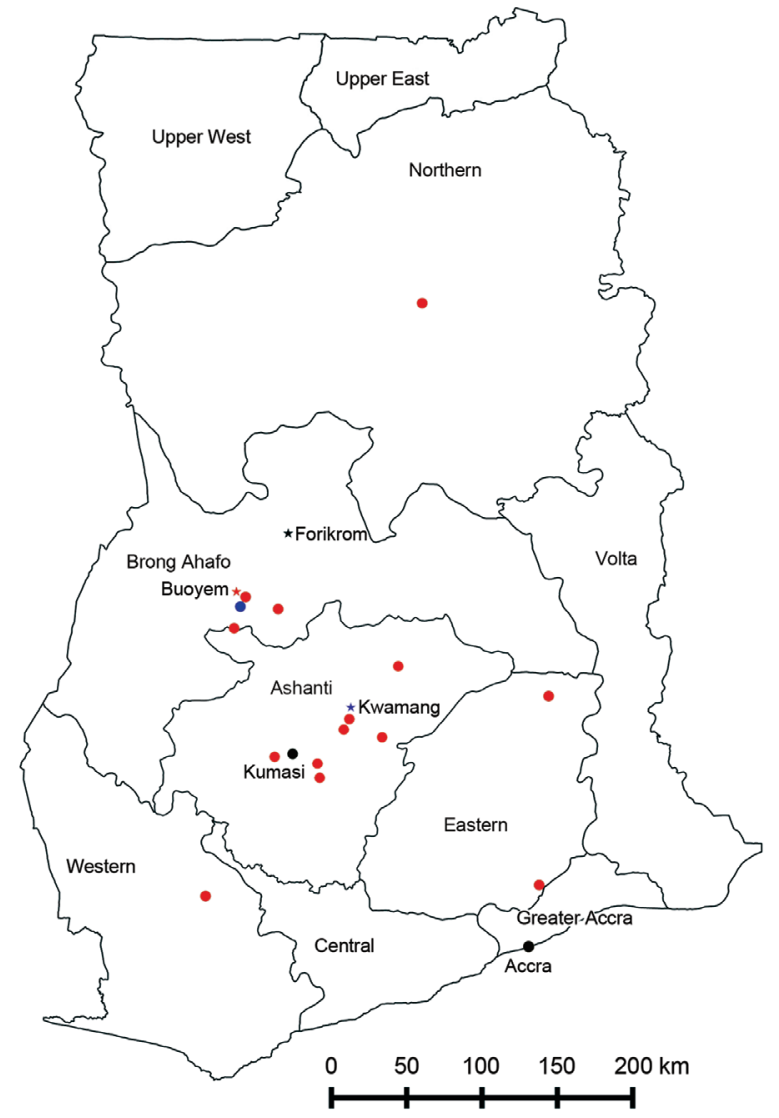

Figure 1. Human-bat interaction study locations and provinces within Ghana, 2011-2012. Asterisks indicate the study sites, Kwamang, Forikrom, and Buoyem. Red circles indicate sources of bush meat. The main Techiman market is situated in the Techiman municipality (blue circle); this market is $\approx 15 \mathrm{~km}$ from Buoyem and is the largest and most economically active market in the Brong Ahafo region. Accra and Kumasi, the largest cities in Ghana, also receive supplies of bat meat from the Techiman market. 

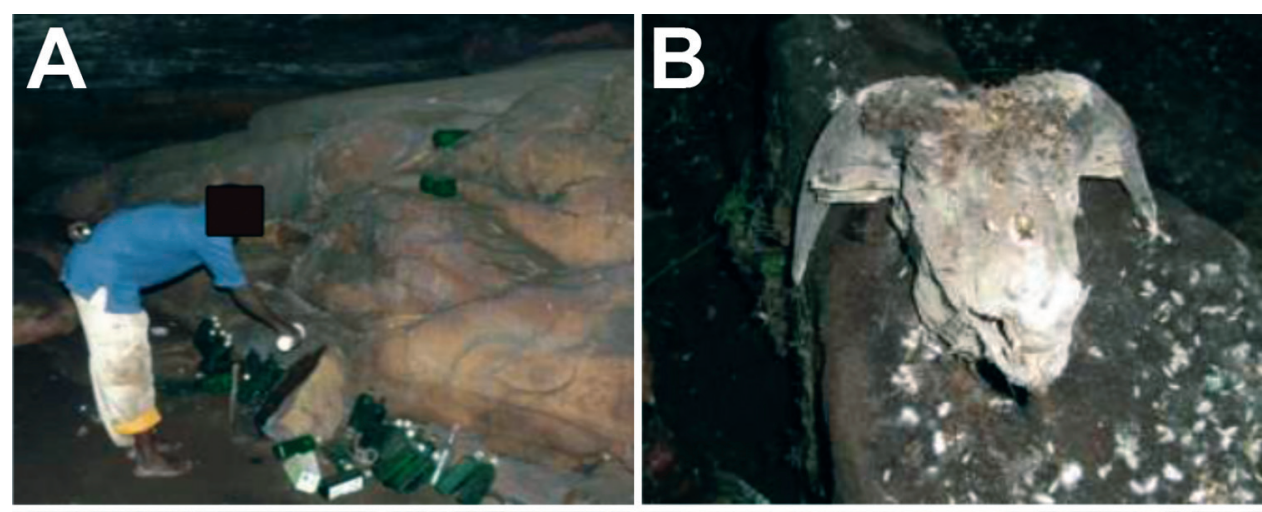

Figure 2. Typical situations in which direct and indirect bat-human contact occurred in Ghana, 2011-2012. A) Religious activity at the Mprisi cave in Buoyem. The man is pouring libation to the natural gods. The liquid poured before entering the cave is liquor. Note the number of deposited empty bottles, indicating the frequency of cave entries. B) Goat sacrificed for natural gods at the Mframmabuom cave in Kwamang. C, D) Typical
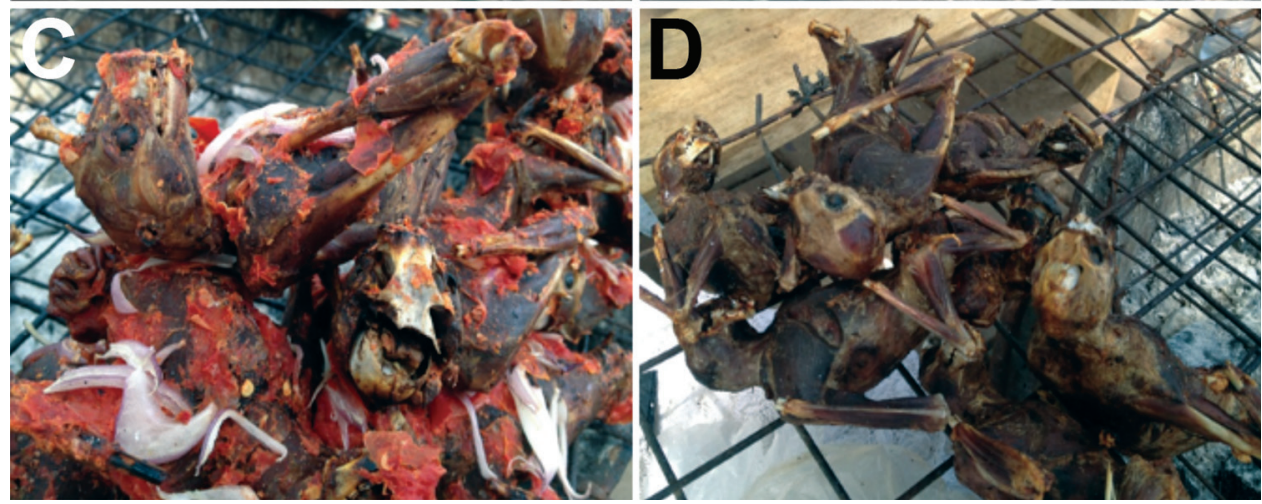
examples of roasted bats widely offered and consumed in markets and public places in Ghana. Photographs provided by and published with permission from $\mathrm{H}$. Baldwin.

in Yam activities for reasons explained as cleanliness. In recent years, Yam activities had been discontinued because of chieftaincy disputes and conflict over ownership of cave lands. Traditional authorities in Kwamang and Forikrom did not report similar cultural activities in connection with bats.

Regular human activities were directly observed at all cave sites, including the Mprisi (Figure 2, panel A) and Dwamerewa caves in Bouyem, Boten cave in Forikrom, and Mmframabuom and Ohene Abutia caves in Kwamang (Figure 2, panel B). The Ohene Abutia cave served as one of the major water sources in the Kwamang community. Several caves served as spiritual sanctuaries. Focus group discussions were conducted in all communities (online Technical Appendix, http://wwwnc.cdc.gov/EID/ article/21/8/14-2015-Techapp1.pdf).

Structured household survey questionnaires were received back from 1,274 respondents: 32.3\% from Buoyem, $28.4 \%$ from Forikrom, and 39.2\% from Kwamang. Contact with bats was reported by 841 (66\%) respondents; bat bites, scratches, or urine exposure was reported by 476 (37.4\%) respondents. Almost half (594 [46.6\%]) of respondents visited bat caves frequently; $217(17 \%)$ reported coming into contact with bats only in their normal living or work environment (Table). The proportion of respondents who deliberately visited caves was significantly higher than the proportion exposed only in their living and work environments $(\mathrm{p}<0.001)$.
Bat species identification was based on observations and standard illustrated field guides (10). Focus group participants identified bats species by using standard images of species recorded from each study site. Observed insectivorous bats included Nycteris spp. (Nycteriidae), Hipposideros jonesi, $H$. aff. Ruber, $H$. gigas, and $H$. abae (Hipposideridae); observed fruit bats included Hypsignathus monstrosus, Rousettus aegyptiacus, and Eidolon helvum (Pteropodidae). These bat species are known to carry coronaviruses (particularly Hipposideridae bats) (11); hantaviruses (particularly Nycteridae bats) (12); paramyxoviruses, including henipavirus (13); and filoviruses (14).

Trading of roasted and fried bats was widely observed in market places (Figure 2, panel C, and Figure 1, panel D). Initial information about the supply routes of bat meat obtained from hunters and members of the indigenous community led to investigation of the bat meat trade at the main market in Techiman. Hunters from the surrounding communities supplied most traded bats. Information gathered from traders showed that the supply route of bat meat extends far beyond the Brong Ahafo region to other regions in Ghana and neighboring countries (Figure 1). Some places mentioned by the traders as sources of bat meat include towns and villages in the Ashanti region. Some of these were Duamo (3 km from Kwamang), Adobomam, Kyekyebon, Kumawu, Deduako, Agogo, and the zoological gardens in Kumasi, where migratory E. helvum bats roost 
Table. Modes of human-bat contact and purposes of cave visitation, Ghana, 2011-2012

\begin{tabular}{|c|c|c|c|}
\hline \multirow[b]{2}{*}{ Contact } & \multicolumn{3}{|c|}{ Community, no. (\%) } \\
\hline & Buoyem, $n=412$ & Forikrom, $\mathrm{n}=362$ & Kwamang, $n=500$ \\
\hline Respondents reporting bat contact & $263(63.8)$ & $244(67.4)$ & $334(66.8)$ \\
\hline In houses through broken ceilings & $69(16.7)$ & $51(14.1)$ & $65(13)$ \\
\hline In bat roosts on farms & $41(10)$ & $28(7.7)$ & $63(12.6)$ \\
\hline In caves & $129(31.3)$ & $161(44.5)$ & $187(37.5)$ \\
\hline At work places & 0 & $1(0.3)$ & 0 \\
\hline In school buildings & $24(5.8)$ & $3(0.8)$ & $5(1)$ \\
\hline In other areas & 0 & $\begin{array}{l}-10 \\
0\end{array}$ & $14(2.8)$ \\
\hline Respondents visiting bat caves & $181(43.9)$ & $178(49.3)$ & $222(44.4)$ \\
\hline For religious activities & $19(4.6)$ & $79(21.8)$ & $5(1)$ \\
\hline For recreation & $58(14.1)$ & $73(20.2)$ & $46(9.2)$ \\
\hline To collect bat guano & 0 & $14(3.9)$ & $2(0.4)$ \\
\hline To fetch water & $1(0.2)$ & 0 & $123(24.6)$ \\
\hline To hunt for bats & $102(24.8)$ & $6(1.7)$ & $10(2)$ \\
\hline To farm & $9(2.2)$ & $17(4.7)$ & $33(6.6)$ \\
\hline For other reasons & $2(0.5)$ & $5(1.4)$ & $14(2.8)$ \\
\hline
\end{tabular}

seasonally (13). Other areas were in Techiman, Nkoranza, Tanoso, and Tuobodom in the Brong Ahafo region; Afram Plains and Akuapem in the Eastern region, and Accra in the Greater Accra region. Some supplies came from the Northern region and beyond the borders of Ghana from Côte d'Ivoire.

Of the 1,274 respondents, $581(45.6 \%)$ reported having consumed bats. Among these, $257(44.2 \%)$ respondents were from Buoyem, 141 (24.2\%) from Forikrom, and 183 (31.5\%) from Kwamang (online Technical Appendix Table 1). Of the 581 respondents who ate bat meat, 237 (40.8\%) obtained bats from caves, $123(21.1 \%)$ caught bats on farms with bat roosts, 114 (19.6) bought bats from community markets, and $60(10.3 \%)$ bought bats from restaurants as part of meals served. Most respondents described the consumed animals as "big bats," suggesting that most were fruit bats (Pteropodidae).

To identify the factors associated with bat consumption, we compared determinant variables for the 581 respondents who consumed bats and the 690 who did not (online Technical Appendix Table 2). Bat meat was eaten by a significantly higher percentage of men than women $(p<0.001)$ and a significantly higher proportion of farmers than those with other occupations $(\mathrm{p}<0.001)$. To determine the variables that significantly influenced the consumption of bat meat, we entered all significant variables into a logistic regression model. The odds of consuming bat meat were higher for men (odds ratio 2.47; 95\% CI 1.93-3.17) than for women and for respondents $>25$ years of age (odds ratio 4.14; 95\% CI 2.91-5.89) than for those $\leq 25$ years of age (online Technical Appendix Table 3).

A second multivariate analysis, conducted to determine factors that predict visitation of bat caves, indicated that older age and male sex were significantly associated with visitation of bat caves (online Technical Appendix). The association between cave visitation and bat consumption was significant $\left(\chi^{2}=75.6 ; p<0.001\right)$; odds of eating bat meat were twice as high among respondents who visited bat caves (odds ratio 2.74) than among those who did not.

\section{Conclusions}

The deliberate entry into bat caves represents a prevalent behavior that could be influenced by communitylevel education in the aftermath of the ongoing outbreak of Ebola virus disease in West Africa. Another obvious target is the widespread bat meat trade and consumption. Further research will be necessary for understanding belief systems and developing acceptable guidance for rural communities exposed to bats because of traditional and spiritual reasons.

\section{Acknowledgments}

We are grateful to the chiefs and citizens of the communities of Buoyem, Kwamang, and Forikrom.

This study was supported by Deutsche Forschungsgemeinschaft within the Africa Infectious Diseases program through grants to C.D. and Y.A.-S. (DR 772/3-1) and to O.A., S.O., and M.T. (KA1241/18-1).

Ms. Anti is an MSc student at Kwame Nkrumah University of Sciences and Technology, Kumasi, Ghana. Her research focuses on the influence of human behavior on zoonotic disease transmission.

\section{References}

1. Messenger SL, Rupprecht C, Smith C. Bats, emerging virus infections and the rabies paradigm. In: Kunz TH and Fenton MB, editors. Bat ecology. Chicago: University of Chicago Press; 2003. p. 622-79.

2. Bausch DG, Schwarz L. Outbreak of Ebola virus disease in Guinea: where ecology meets economy. PLoS Neg1 Trop Dis. 2014;8:e3056. http://dx.doi.org/10.1371/journal.pntd.0003056

3. Wong S, Lau S, Woo P, Yuen KY. Bats as a continuing source of emerging infections in humans. Rev Med Virol. 2007;17:67-91. http://dx.doi.org/10.1002/rmv.520 
4. Annan A, Baldwin HJ, Corman VM, Klose SM, Owusu M, Nkrumah EE, et al. Human betacoronavirus 2c EMC/2012-related viruses in bats, Ghana and Europe. Emerg Infect Dis. 2013; 19:456-9. http://dx.doi.org/10.3201/eid1903.121503

5. Hayman DT, Yu M, Crameri G, Wang LF, Suu-Ire R, Wood JL, et al. Ebola virus antibodies in fruit bats, Ghana, West Africa. Emerg Infect Dis. 2012;18:1207-9. http://dx.doi.org/10.3201/ eid1807.111654

6. Drexler JF, Corman VM, Muller MA, Maganga GD, Vallo P, Binger T, et al. Bats host major mammalian paramyxoviruses. Nat Commun. 2012;3:796. http://dx.doi.org/10.1038/ncomms 1796

7. Kamins AO, Restif O, Ntiamoa-Baidu Y, Suu-Ire R, Hayman D, Cunningham A, et al. Uncovering the fruit bat bushmeat commodity chain and the true extent of fruit bat hunting in Ghana, West Africa. Biol Conserv. 2011;144:3000-8. http://dx.doi. org/10.1016/j.biocon.2011.09.003

8. Paterson BJ, Butler MT, Eastwood K, Cashman PM, Jones A, Durrheim DN. Cross sectional survey of human-bat interaction in Australia: public health implications. BMC Public Health. 2014;14:58. http://dx.doi.org/10.1186/1471-2458-14-58

9. Baize S, Pannetier D, Oestereich L, Rieger T, Koivogui L, Magassouba N, et al. Emergence of Zaire Ebola virus disease in Guinea. N Engl J Med. 2014;371:1418-25. http://dx.doi.org/ 10.1056/NEJMoa1404505

10. Rosevar DR. The bats of West Africa. London: British History Museum; 1965.

11. Pfefferle S, Oppong S, Drexler JF, Gloza-Rausch F, Ipsen A, Seebens A, et al. Distant relatives of severe acute respiratory syndrome coronavirus and close relatives of human coronavirus 229E in bats, Ghana. Emerg Infect Dis. 2009;15:1377-84. http://dx.doi.org/10.3201/eid1509.090224

12. Witkowski PT, Klempa B, Ithete NL, Auste B, Mfune JK, Hoveka J, et al. Hantaviruses in Africa. Virus Res. 2014;187:34-42. http://dx.doi.org/10.1016/j.virusres.2013.12.039

13. Drexler JF, Corman V, Gloza-Rausch F, Seebens A, Annan A, Ipsen A, et al. Henipavirus RNA in African bats. PLoS ONE. 2009;4:e6367. http://dx.doi.org/10.1371/journal.pone.0006367

14. Leroy EM, Kumulungui B, Pourrut X, Rouquet P, Hassanin A, Yaba $\mathrm{P}$, et al. Fruit bats as reservoirs of Ebola virus. Nature. 2005;438:575-6. http://dx.doi.org/10.1038/438575a

Address for correspondence: Christian Drosten, Institute of Virology, University of Bonn, Sigmund Freud St, 25, 53105 Bonn, Germany; email: drosten@virology-bonn.de

\section{Check out EID's 20-year-anniversary timeline and find an array of fascinating seminal moments in the journal's history.}
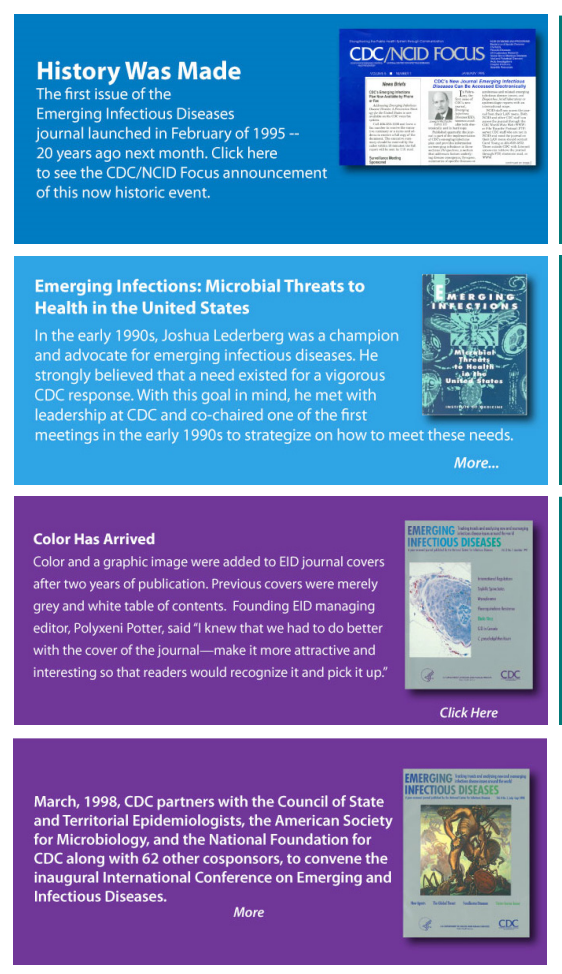
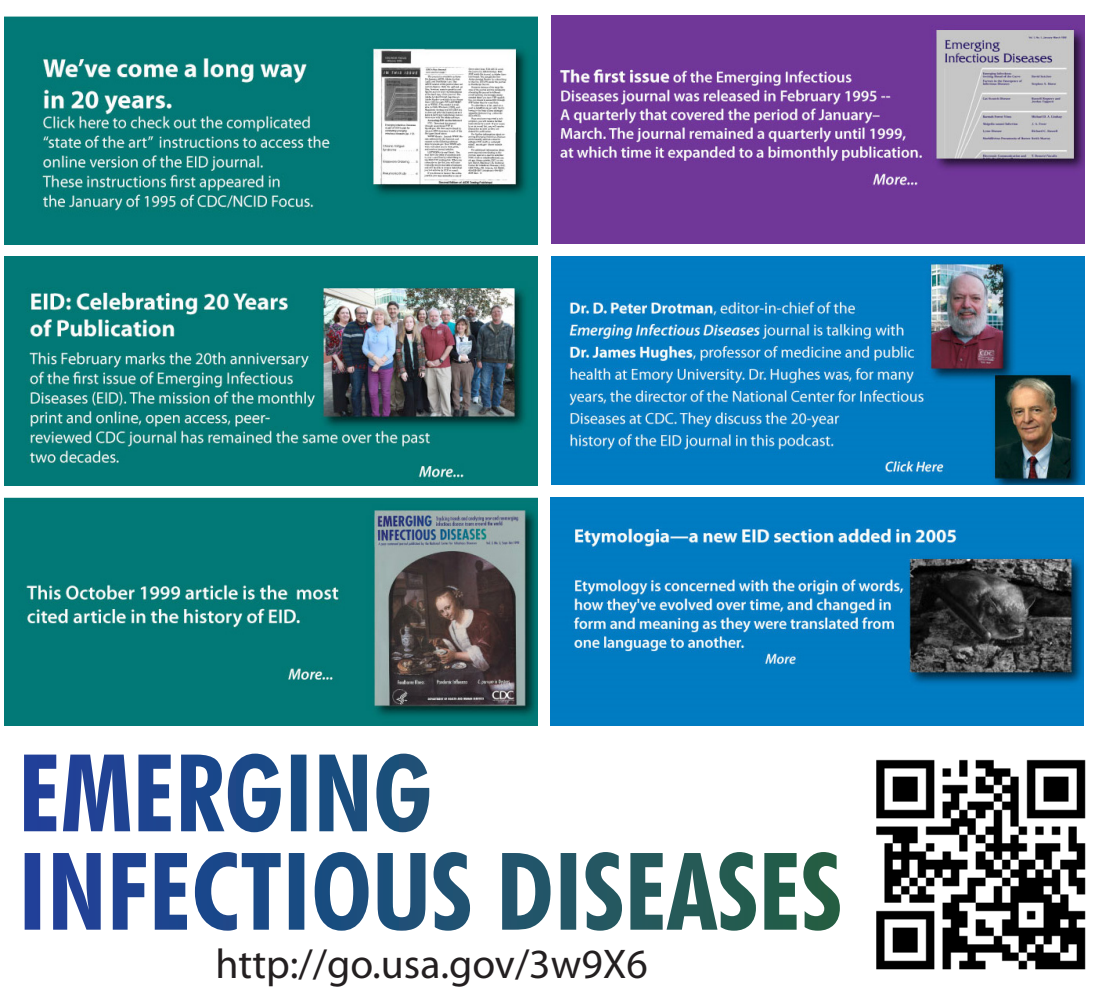